\title{
Antonio Candido e José Mindlin
}

\section{Entrevistadora: Walnice Noguelra Galvão}

\section{Em torno do Modernismo ${ }^{1}$}

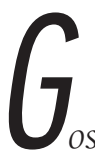

ostaria que ambos relatassem seus primeiros contatos com o Modernismo. A transição do cânone tradicional para o cânone modernista implicou em transgressão ou aventura estética? Quem foram seus Virgílios, ou seja, os mediadores desse percurso? Que papel tiveram Henrique Mindlin e Rubens Borba de Moraes para José Mindlin, ou Mário de Andrade e Oswald de Andrade para Antonio Candido?

José Mindlin: Curiosamente, meu contato com o Modernismo foi tardio. Cresci num ambiente cultural, meu pai era apaixonado por artes plásticas, mas era um autodidata que chegou ao Brasil em 1910. Menos de dois anos depois foi fundada a Sociedade de Cultura Artística e ele se tornou um dos primeiros sócios, pois era amigo do Nestor Rangel Pestana. Mas o interesse dele por pintura, naquela época, e até praticamente os anos 30, era pela pintura acadêmica. Meu irmão Henrique teve um pouco mais de contato do que eu. Eu diria que a minha

\footnotetext{
${ }^{1}$ Para falar sobre o Modernismo, dispuseram-se a atender à solicitação de D.O. Leitura o crítico literário Antonio Candido e o bibliófilo José Mindlin. Ambos tiveram sua trajetória marcada pelo contacto com o Modernismo e com os modernistas. Ambos se entregaram de coração à nova estética, que apreciaram, estudaram e divulgaram. Antonio Candido, quando crítico militante de jornal, dedicou rodapés a seus principais escritores. Mais tarde, introduziria o estudo do Modernismo na Universidade de São Paulo. Quanto a José Mindlin, além de colecionar as primeiras edições de todos eles, foi pioneiro na iniciativa de reeditar em fac-símile as principais revistas do movimento. Ambos nos falam dessas experiências e das amizades que delas resultaram.

Entrevista reproduzida de D.O. Leitura, Imprensa Oficial, São Paulo, Ano 20, Nos. 1 e 2, jan./fev. de 2002. Ajustes feitos pela entrevistadora WNG.
} 
integração com o Modernismo foi a partir de 40. Henrique foi morar no Rio, era um arquiteto modernista, e ganhou em 41 o primeiro prêmio num concurso para o novo prédio do Itamaraty. E fez uma coisa primorosa de arquitetura moderna, integrado com o primeiro grupo de arquitetos modernistas do Rio: o Reidy, os irmãos Roberto, Vital Brasil, todos eles. Também fiquei conhecendo a todos, por intermédio do Henrique. Ele tinha boa amizade com o Portinari, a quem a gente ainda olhava com certa reserva. De Picasso, por exemplo, eu tinha a sensação de que fosse cabotino, não via nele o artista. Gostava da primeira fase, a fase azul e rosa. Mas eu vi em 66 uma retrospectiva dele em Paris que me mudou radicalmente: concluí que esse homem era um gênio, porque a gente via como de um ano para outro mudava completamente o estilo, dominava a técnica de tal forma que não se podia negar que ele tinha o direito de fazer o que quisesse.

Vou repassar a pergunta a Antonio Candido...

Antonio Candido: Já fiquei mais animado porque pensava que era para falar historicamente sobre essa questão de arte moderna. Sobre a experiência da gente é canja, não tem problema.

Minha experiência é bastante parecida com a do José. Quase tomaria a do José como paradigma. Para a formação cultural do jovem, do adolescente, às vezes tem aspectos positivos e tem aspectos negativos o fato de você vir de uma família culta. O José, por exemplo, era filho de pais cultos em São Paulo, eu era filho de pais cultos no interior de Minas. Ele tinha em volta dele uma vida cultural importante, eu só tinha meu pai, minha mãe e a biblioteca deles. Portanto, estava no passado. Porque tinha só a biblioteca de meu pai e minha mãe... uma excelente biblioteca que você, Walnice, viu em Poços de Caldas...

Vi, sim. Hoje está na Unicamp, não é?

AC: Parte está na Unicamp. De modo que a minha formação foi como a do José, toda mergulhada no passado. Eu lia Alexandre Herculano, Anatole France, lia Renan, essa gente toda.

JM: Ah, também vou falar deles...

AC: Na minha casa, meu pai e minha mãe não tinham a menor noção do que fosse Modernismo. Lá no interior de Minas não chegava ninguém que soubesse disso. Tenho a impressão que as primeiras noções que tive do Modernismo chegaram através de revistas. Meu pai assinava o Boletim de Ariel e recebia Lanterna verde, da Sociedade Felipe de Oliveira. Ali estavam os modernistas presentes, falavase em Cubismo, tinha reproduções de Lasar Segall, tinha poemas modernos, tinha Murilo Mendes, Manuel Bandeira... Eu achava aquilo muito curioso. Lembro que em 1933, estava fazendo quinze anos, passei algum tempo hospitalizado no Rio, 
por causa de um desastre; uma prima me levava livros, inclusive Libertinagem, de Manuel Bandeira. Eu li e achei muito divertidos poemas como "Atirei um céu aberto / na janela do meu bem: / caí na Lapa - um deserto... / - Pará, capital Belém!..." Mas considerei aquilo uma brincadeira. Posso dizer que a minha experiência com a modernidade não foi através do Modernismo, foi com a leitura dos romancistas do decênio de 1930, pelos quais me apaixonei: Jorge Amado, Amando Fontes, Graciliano Ramos, José Lins do Rego, Rachel de Queiroz, Érico Veríssimo.

Foi pelo romance de 30 que o senhor começou?

AC: Foi por eles que comecei quando tinha 14 anos. Tive sorte, porque morava em Poços de Caldas, que naquele tempo era uma estação balneária da moda e então havia lá, surpreendentemente, uma excelente livraria, inclusive com livros franceses e ingleses. Nessa livraria encontrei Primeiro andar, de Mário de Andrade, e - surpreenda-se - Serafim Ponte Grande, de Oswald de Andrade. Vou dizer mais: nos meus numerosos anos de vida foi a única vez - única - que vi Serafim Ponte Grande à venda numa livraria.

Não diga! Quem imaginaria, não é? E como era o nome dessa livraria?

AC: "Vida Social", do Dr. Cornélio Tavares Hovelaque. Foi só lá. Não levei para casa porque tinha muito palavrão, então eu e um amigo decidimos ler ali mesmo, na livraria, o Serafim Ponte Grande. Achei divertidíssimo, mas não percebi o valor real. Repito que a paixão inicial foi pelo chamado Segundo Modernismo. Sobretudo porque estava ligado ao ângulo social: eram o pobre, o oprimido, o operário, o negro. De modo que travei contato sem entusiasmo com o Modernismo através do Boletim de Ariel, da Lanterna verde, do Serafim Ponte Grande, do Primeiro andar, de poesias de Murilo Mendes, Carlos Drummond de Andrade, mas não sabia direito do que se tratava. Para dar uma ideia da minha ignorância, eu achava que Sérgio Milliet era um escritor francês...

JM: Muita gente pensa isso até hoje.

AC: ...como Blaise Cendrars. Vim para São Paulo em 1936. Do ponto de vista artístico, por exemplo, isso de que o José estava falando, só tive consciência, só me emocionei com o Modernismo no Segundo Salão de Maio, no Hotel Esplanada. Acho que em 1938. Aí tive uma forte impressão da pintura, sobretudo a pintura revolucionária de Carlos Prado, da qual gostei muito. Mas gostei mais de Flávio de Carvalho.

Carlos era irmão do Caio Prado Jr., não era?

AC: Era o irmão do Caio: fazia uma pintura social. Mas fiquei apaixonado pelo Flávio de Carvalho. Nesse tempo li o livro de um crítico italiano chamado 
Guido Severini, que era futurista: Raggionamenti sulle arti figurative, que me ajudou a entender a Arte Moderna. De modo que foi esse o meu começo. É preciso dizer que a gente não podia ler os modernistas, porque eles não eram acessíveis, não existiam em livrarias. Do Serafim Ponte Grande foram tirados quinhentos exemplares, que ficaram empilhados no apartamento do Oswald, no Rio. Mário de Andrade custeava os seus livros, tirados a mil exemplares, seiscentos exemplares. Você não encontrava para comprar. Quando eu era estudante, passei em frente ao Gazeau, na Praça da Sé, e vi empilhados uns vinte exemplares novinhos de Há uma gota de sangue em cada poema, para vender. Olhei aquilo, sabia que era de Mário de Andrade, comprei três a dez tostões cada um. Outro dia o Edgard Carone me contou que um americano pagou mil reais por um exemplar desse livro. Se eu fosse uma pessoa sensata tinha comprado os vinte.

Claro.

AC: Você não encontrava os livros. Eu tinha muita vontade de ler Mário de Andrade, mas só li Primeiro andar e Macunaima, que um amigo me emprestou. Até que, quando entrei na Faculdade de Filosofia, no bacharelado, em 1939, conheci a Gilda (Rocha de Mello e Souza) e ela me emprestou muitos livros de Mário de Andrade. Eu os levei para Poços de Caldas e li durante as férias de 39-40. Fiquei absolutamente fascinado, a tal ponto que resolvi copiar à mão Paulicéia desvairada. Não cheguei ao fim, mas comecei. Veja como era difícil para um jovem, no decênio de 1930, o conhecimento do Modernismo e dos modernistas. Ao contrário, eram acessíveis os romances do momento. De modo que foi por aí que eu entrei na modernidade literária.

Esses romances foram muito vendidos?

AC: Relativamente. Por exemplo, Menino de engenho foi um grande sucesso, teve logo segunda edição. Então saiu Doidinho, pela Editora Ariel, e teve certo sucesso. O José Olympio se embandeirou e quando editou Bangüê tirou dez mil exemplares, coisa enorme para o tempo. Mas o livro encalhou. Anos depois era possível encontrar essa primeira edição com a mesma capa de Santa Rosa.

JM: Foram esses que eu li também. Você mencionou Renan, também li muito, bem como Anatole France e Romain Rolland.

AC: Anatole France tem livros notáveis.

Mencione um livro notável de Anatole France.

AC: Les dieux ont soif, La rôtisserie de la reine pédauque, L'orme du mai, Le mannequin d'osier são livros extraordinários. Devo confessar que L’orme du mai e o Le mannequin d'osier li umas dez vezes cada um. 
Tudo isso! E o que o senhor ia dizer de Romain Rolland?

JM: Também é um grande escritor e hoje também injustamente meio esquecido. Quando papai morreu, em 39, eu estava lendo o Jean Christophe.

Está me ocorrendo agora: talvez fosse menos agressiva a inovação no romance nordestino do que na poesia?

JM: Ah, era mesmo.

Então devia ser menos doloroso e exigir menor adaptação começar por aí. E depois chegar à parte mais difícil: a poesia.

AC: Há duas coisas. Primeiro, aquele romance nordestino era neorrealista, perfeitamente acessível. Enquanto a poesia modernista requeria uma adaptação muito grande. Além do mais, os romances você encontrava para comprar, a poesia não encontrava.

JM: É claro que esse é um fator importante.

AC: Devo dizer que a partir de 39 começou para mim uma fase nova: a das relações com os modernistas. Em 39, com Décio de Almeida Prado e Paulo Emílio Salles Gomes, fui fazer uma visita a Mário de Andrade, intermediada pela Gilda. Nunca fui propriamente amigo dele, mas tivemos boas relações. Conheci logo a seguir Oswald de Andrade. Ele recebia aos domingos e nós íamos a sua casa.

\section{Quem mais?}

AC: Sérgio Milliet só fui conhecer em 1941; depois convivi muito com ele na Associação Brasileira de Escritores, a ABDE: ele foi presidente e eu segundo secretário, na primeira gestão. Conheci Guilherme de Almeida e tive algum contato com ele em 1943 e 1944, quando ambos colaborávamos na Folha da Manhã. Conheci Rubens Borba de Moraes e fui muito amigo dos irmãos Paulo Mendes de Almeida e Fernando Mendes de Almeida, modernistas mais jovens que se formaram à sombra dessa gente. Aí fiquei mais ou menos integrado na atmosfera paulista do Modernismo. Porque eu faço uma distinção entre o Modernismo carioca, mais moderado, e o Modernismo paulista, mais combativo. O que o Guilherme de Almeida era aqui em São Paulo, o Ronald de Carvalho era no Rio.

Os dos paulistas eram textos de ruptura, que me assustavam no começo, embora me atraíssem. Assim eram também os de Carlos Drummond de Andrade, influenciado pelos paulistas. Nos anos $30 \mathrm{eu}$ li poemas dele no Boletim de Ariel e lembro o choque que me causaram, a exemplo de "Os mortos de sobrecasaca". 
Chegamos então à sociabilidade modernista, essa camada de intelectuais, artistas e aderentes que havia aqui em São Paulo e que depois vai dar na criação do Clube dos Artistas e do Museu de Arte Moderna. Não é isso, mais ou menos?

AC: Havia em São Paulo coisas interessantes de que não participei. O Azis participou, era muito ligado a esse pessoal e me contou como foi.

Quem? Azis Simão?

AC: Azis Simão. Era amigo do Oswald de Andrade e trabalhava no São Paulo Jornal com Cândido Mota Filho, que é um modernista da ala do Plínio Salgado, Menotti del Picchia, Cassiano Ricardo. O Azis conhecia essa gente toda e se dava muito com o Caio Prado Jr. Um certo grupo fundou o Clube de Arte Moderna que o Azis frequentava e onde assistia às discussões do Caio. Foi uma atmosfera que eu não peguei. Depois o Paulo Emílio tentou fundar o Quarteirão, que não foi para diante: ele, o Décio, dona Vera Vicente de Azevedo e outros. Mas eu ainda estava em Minas, ignorava tudo isso e nem ouvi falar de coisas famosas como o baile à fantasia "Carnaval na Cidade de SPAM" (Sociedade Paulista de Arte Moderna).

JM: Nesse baile eu estive.

O senhor foi ao famosíssimo baile da SPAM?

JM: Fui. No Museu Lasar Segall há uma fotografia do grupo, eu e meus irmãos estávamos lá. Era um baile de carnaval bem diferente do usual pois tinha um conteúdo artístico, mas nem por isso era menos divertido.

Não eram aqueles bailes com roteiro de Mário de Andrade e cenografia de Lasar Segall?

JM: Exatamente, a cenografia era dele.

AC: Nada disso eu peguei. Vivia aqui em São Paulo em 36, 37 e 38 totalmente fechado ainda no meu velho mundo, indo ver conferências de professores franceses. Dos meus amigos era o único que ia à Pinacoteca, ninguém mais dava bola para a arte acadêmica.

JM: Que era naquela rua... perto da 11 de Agosto.

AC: Isso mesmo. Eu frequentava as exposições no Palacete das Arcadas, na Quintino Bocaiúva, onde vi Helios Seelinger, Hernani de Irajá, Oscar Pereira da Silva e outros, até que o Segundo Salão de Maio me deu o choque em 38. Quan- 
do entrei em 39 na Faculdade, as coisas se abriram, porque se falava em Mário de Andrade, Oswald de Andrade, como se fosse coisa corrente. Como não conhecia as pessoas, eu não as identificava na rua. São Paulo tinha um milhão de habitantes, você saía de casa e volta e meia via Oswald de Andrade, Mário de Andrade, Cassiano Ricardo, Menotti del Picchia, Guilherme de Almeida.

Ainda mais que a Faculdade era no centrinho...

JM: Era uma época em que você não podia passar pelo Viaduto do Chá sem encontrar meia dúzia de conhecidos. Mas você falou no Paulo e Fernando Mendes de Almeida: fui amigo deles e tenho o livro Cartazes, do Paulo, acho que é de 28 .

AC: Também tenho Cartazes: é de 28. Uma capa bem modernista.

Ele fazia crítica de artes plásticas, não é?

AC: Fazia.

JM: Agora, vejo que estava esquecendo que meus contatos com o Modernismo foram anteriores a 1940. Entrei na redação de O Estado de S. Paulo em 30, tinha quinze anos e meio. Lá fiquei muito amigo do Guilherme de Almeida, que fazia crônica social, assinando-se Gui. O Afonso Schmidt também era da redação, parte de um grupo literário, mas não era o grupo modernista: Léo Vaz, Sud Menucci, Amadeu Amaral Júnior, por exemplo. Mas foi lá que fiquei amigo do António de Alcântara Machado.

Mas era um pessoal tingido de Modernismo?

AC: O Estado de S. Paulo, enquanto jornal, resistiu muito ao Modernismo. Inclusive eles não permitiam que se escrevesse lá com jargão modernista. O Alfredo Mesquita dizia sempre: "Mário de Andrade quando escreve para o Estado policia a linguagem. Gramaticalmente, tudo direitinho".

Voltando mais para trás, queria perguntar sobre o seu outro Virgílio do Modernismo, que é Rubens Borba de Moraes: ele participou da Semana?

JM: Ele ajudou a organizar, mas teve tifo durante a Semana, por isso não esteve presente. O Rubens era primo de uma cunhada minha, a Helena Muniz de Souza, que foi casada com o Henrique. Então a gente se conheceu, já nos anos 30; o livro nos aproximou, ficamos amigos de vida inteira e ele passou a ser o irmão mais velho meu. É o interlocutor que me falta, não encontrei ninguém, depois que ele morreu, que pudesse substituí-lo nas conversas. O Rubens era de 
uma cultura muito sólida e de uma irreverência intelectual muito grande. O Giordano fez agora um fac-símile do livro Domingo dos séculos. Você conhece, não é?

AC: Você me emprestou, eu li. É um livro encantador, é uma conversa.

JM: Ele tinha contato com todo mundo, daí a minha amizade com Paulo Duarte, por exemplo. Agora, Paulo Duarte não se pode classificar como modernista.

AC: Ele era daquele grupo muito infenso ao Modernismo ligado a Amadeu Amaral, Júlio de Mesquita, admiradores de Olavo Bilac: aquela gente toda que era o grupo dele e não gostava do Modernismo.

Mas Paulo Duarte vai dar uma força muito grande a Mário de Andrade, não é?

AC: Em seguida sim, mas isso já mais tarde...

Quando assentou a poeira?

AC: Ele pegou o Mário de Andrade militante, não o Mário de Andrade modernista. Ao Mário de Andrade militante intelectual, ele deu uma força.

JM: Eu tinha contato com os modernistas, mas não cheguei a me integrar, aquilo não ficou fazendo parte da minha vida intelectual. Quando Antonio Candido falou em Cartazes me veio esse estalo, eu já tinha esses contatos e no jornalismo se encontra muita gente. Mas quando passei a apreciar o Modernismo, não houve ruptura. E não só não foi ruptura, como no campo literário houve muita coisa anterior ao Modernismo de que continuo gostando.

AC: Concordo com o José, para mim também não foi ruptura, foi um acréscimo. Continuei ligado ao passado do mesmo jeito, inclusive fazendo heresias, como essa de ser a única pessoa da minha turma que foi sempre frequentador da Pinacoteca. Ia lá ver Almeida Júnior, Pedro Alexandrino...

JM: Paulo Lopes de Leão era diretor da Pinacoteca quando esta ficava na Rua 11 de Agosto. Depois desapareceu com o largo aberto na frente do Palácio da Justiça e se mudou para o prédio atual.

AC: Desde aquele tempo frequentei a Pinacoteca. Frequentei também depois que foi para o prédio do Liceu de Artes e Ofícios e Gomes Cardim era diretor, até que Walter Wey fez uma reformulação completa e a modernizou.

JM: Eles tinham uma oficina de encadernação nos anos 20, 30. Levei muito livro lá para ser encadernado. Agora, comecei a biblioteca antes dos anos 30, acho que logo passou a ter uma parte de Modernismo. 
O senhor começou a colecionar primeiras edições modernistas ali pelos anos 30 ?

JM: Inicialmente poucas. Mas por falar, por exemplo, no Serafim Ponte Grande, temos aqui um exemplar interessante.

É só falar que o livro aparece, não é? Eé o original manuscrito!

AC: É o próprio, aqui?

JM: É o próprio. Então você vê, minha implicância com o computador é que ele impede o conhecimento do processo de criação. A pessoa corrige na hora: aqui vê-se como ele preparou a obra. E afirmei que comecei o contato em 40, mas começo a ver que foi bem antes. Na Revolução de 32 foi organizada uma exposição de quadros para serem vendidos em benefício das vítimas da guerra. Lá eu conheci também o Brecheret e muitos outros artistas.

AC: Devo dizer que tive meu período de Hipermodernismo. Eu era um jovem crítico agressivo e cheguei a escrever que a literatura brasileira começa praticamente em 1922. Naquele tempo fiquei realmente fascinado pelo Modernismo, mas continuo achando que foi um movimento fantástico, porque não foi só um movimento literário, mas um movimento espiritual que mudou a visão do Brasil. Era um grupo pequeno, aqui, no Rio, Rio Grande do Sul, Minas... Mas mudou, inclusive permitiu algo muito importante que foi a redefinição do nacionalismo. $\mathrm{O}$ nacionalismo é uma coisa muito perigosa. Na Europa dá fascismo e aqui também pode dar, mas é frequentemente fator positivo. Como disse muito bem Pontes de Miranda, o socialismo dos países antigos pode ser internacionalista, mas o socialismo dos países novos tem que ser nacionalista devido à necessidade de lutar contra o imperialismo. Pontes de Miranda dizia isso em 1924. Os modernistas forneceram elementos para se fazer uma redefinição do nacionalismo, diferente de "pátria amada, salve, salve". Nacionalismo para eles foi trazer à cena o negro, o imigrante, o índio, o marginalizado; daí vem António de Alcântara Machado com Brás, Bexiga e Barra Funda. Quando ali por 40, 41, 42, cheguei a essa conclusão que estou expondo, fiquei hipermodernista. Fiquei achando que o Modernismo foi uma revolução espiritual.

JM: O "hiper" eu não tive, mas por exemplo, dona Olívia Guedes Penteado era da diretoria da Cruzada Artística e papai foi um dos organizadores. Você se lembra do José Gonsalves, com s, foi outro diretor, era um paulista desses bem emperrados...

Não era a Sociedade de Cultura Artística, era outra coisa?

JM: Foi uma exposição feita na Líbero Badaró com doações de quadros. Este quadro, por exemplo, este Segall foi doado à Cruzada Artística e depois papai 
comprou: era para vender em benefício das vítimas da guerra. Agora que estou pensando nisso, eu achava essa gente bastante normal.

\section{E o senhor começou a se tornar um militante de arte moderna também?}

JM: Também não foi algo planejado, diria que na minha vida nada foi planejado. As coisas foram acontecendo, nunca tive ambição de fazer alguma coisa, de ocupar cargos. O que veio para mim na vida foi fruto de acaso. Agora, quanto à Cultura Artística, foi fundada em 1912 e papai foi um dos primeiros sócios. Quando nós começamos a ir, no fim dos anos 20, eles cobravam cinco mil réis por mês, dando direito a um cavalheiro e duas damas nos recitais. Nos anos $30 \ldots$

Que bons tempos, para cada cavalheiro havia duas damas...

JM: As coisas foram acontecendo. Na vida brasileira você é amigo de fulano, beltrano, sicrano, e qualquer iniciativa que eles tomassem procuravam a gente, qualquer iniciativa que a gente tomasse procurava esses amigos. Então fui entrando, e na Bienal conheci o Cicillo. Uma vez ele me disse: "Você nunca me convidou para jantar em sua casa". Eu disse: "Quem sou eu para convidar Cicillo Matarazzo para jantar em casa?" Ele disse: "Não, estou querendo ir a sua casa". E eu disse: "Ótimo". Ele veio, jantou aqui, conversamos, daí a uns dias ele me convida para ser diretor da Bienal. Ele teve o cuidado de procurar conhecer melhor o ambiente, as ideias. Aí eu entrei na Bienal, fiquei um tempo no Conselho, depois fui eleito presidente. Fiz uma tentativa de ampliar as atividades, acho até hoje que é excessivo o gasto com uma exposição a cada dois anos, uma coisa meio hermética para o grande público. Achava que devia ter atividade permanente de seminários, cursos, e uma exposição nacional alternando com a internacional. João Marino, Luís Villares e eu fizemos aquela exposição de arte brasileira - já vou me lembrar do nome, foi uma linda exposição. Mas depois não vingou... Tradição e ruptura, era o nome. Foi um trabalho muito bom, a exposição era interessante. Depois continuei no Conselho, mas aí começou a haver uma direção que resolvia as coisas e o Conselho da Bienal não dava palpite nenhum. Deixei a Bienal, porque no fundo eu achava que a gente tinha uma responsabilidade pelo que estava sendo feito, sem ter nenhuma possibilidade de interferir.

De colecionador de primeiras edições modernistas a presidente da Bienal de Arte Moderna: e como é que teve a ideia de reimprimir as revistas do Modernismo?

JM: Quando a Metal Leve fez 25 anos, em 1975, começaram a falar em celebração com jantar ou coquetel, eu disse aos companheiros para fazermos uma coisa menos efêmera. A jantar e coquetel as pessoas vão por obrigação, saem criticando e depois esquecem. Não sobra nada como memória. "Vamos fazer uma coisa diferente, vamos reimprimir a Revista de Antropofagia". Acho que foi das 
primeiras empresas que chegou a publicar livros. Depois fizemos a Philomática, esta não tinha nada de Modernismo, era a revista da Sociedade Philomática, publicada em 1832 na Faculdade de Direito. A seguir A Revista, publicada pelo Drummond em 1924, e a revista do Salão de Maio...

E quanto a Klaxon?

JM: Não, Klaxon não.

\section{E Terra Roxa?}

JM: Também não. Aí surgiu um movimento de edições feitas por empresas.

AC: Vocês inspiraram esse movimento.

JM: Eu tinha gosto, não estava fazendo nada de benemérito, estava fazendo porque gostava e achava que era importante. Sempre achei que mais importante do que a própria empresa, era seu papel social: a empresa como instrumento de desenvolvimento social, mas não como uma finalidade em si mesma. Quando começaram a falar em... qual a palavra que se usa para benemerência?

\section{AC: Filantropia?}

JM: Não.

\section{Mecenato?}

JM: Sim, mecenato. Eu reagia, mecenato implica na ideia de favor, empresa que apoia a cultura não faz mais do que sua obrigação.

O senhor publicou também "A visita", poema do Drummond ilustrado...

JM: Tive a ideia, falei com o Drummond... Eu conhecia o Drummond muito superficialmente, encontrava com ele no sabadoyle ${ }^{2}$, aí a gente foi estabelecendo uma relação mais cordial, mas assim mesmo cerimoniosa. Um dia disse ao Plínio Doyle que gostaria de fazer uma edição de arte com alguma coisa do Drummond. O Plínio disse: "Peça você mesmo, porque para mim ele recusa facilmente". Falei com ele, ele agradeceu, disse que gostaria muito, mas não tinha nada de expressivo inédito. Mas disse que estava trabalhando num poema, um tema que o tinha interessado a vida inteira, e que era a visita que Mário de Andrade fez a Alphonsus de Guimaraens, em 1919: se conseguisse terminar o poema me mandaria.

${ }^{2}$ Termo que designava o salão de intelectuais que se reunia aos sábados, em casa de Plínio Doyle, no Rio. 
Dois meses depois recebo um envelope, promessa cumprida, e aí se estreitou a relação. O Drummond gostava muito de arte gráfica, levamos seis meses para determinar o que se ia fazer: formato, papel, tipo a ser usado, ilustração, tudo. Ficamos muito amigos, realmente. Depois que chegamos a definir tudo, levou mais seis meses para fazermos a edição. Aí ele queria corrigir as provas... Mas a minha relação com o Drummond, e a geração mineira... naquele tempo estavam vivos o Afonso Arinos, o Ciro dos Anjos...

Pedro Nava...

JM: Do Pedro Nava também fui amigo.

Eu jantei com ele, e em outra ocasião com Plínio Doyle, aqui em sua casa.

JM: Na conversa com esses escritores que formavam um círculo desde a mocidade, eu tinha a sensação de ter chegado a um banquete na sobremesa, porque não peguei toda a parte da vida em comum deles. Assim mesmo valeu, foi das boas experiências que tive na vida.

Antonio Candido acabou ficando amigo epistolar do Drummond...

AC: As cartas do Drummond para mim eu dei ao José, para ficarem mais seguras: vinte e poucas. Tivemos algum contato, muito boas relações, mas nunca fui à casa dele e nunca convivemos, salvo em 1947, no Segundo Congresso Brasileiro de Escritores, em Belo Horizonte, onde durante uma semana estivemos na mesma comissão e íamos todas as noites tomar chope e cantar no Bar Pingüim, com Rodrigo de Mello Franco de Andrade, Décio de Almeida Prado, Arnaldo Pedroso d'Horta e outros. Eu sou muito esquivo, ele também era. Houve duas vezes em que nos encontramos no Rio e um fingiu que não viu o outro...

Isso é o cúmulo da mineirice, não? Gostaria agora de indagar sobre suas atividades de propagador do Modernismo. Por exemplo, as relações com os acervos de Mário de Andrade e de Oswald de Andrade: como vieram parar em suas mãos, como o senhor idealizou o destino que podia dar a eles, e os frutos que deles resultam até hoje.

AC: Depois que entrei mesmo no Modernismo, a partir de 1939 - tinha 20, 21 anos - achei que devia ser objeto de estudo, me apaixonei, me tornei crítico literário e escrevi muito sobre os poetas da atualidade. Depois que me tornei professor de Literatura, em 58, quando fui para Assis, lá não havia campo para isso. Quando vim para São Paulo, em 61, minha preocupação foi instalar o estudo do Modernismo na universidade. Há uma tradição universitária, não brasileira, mas universal, de você só estudar autores mortos. Tem uma certa justificativa: a obra está pronta e não será mais alterada, você tem uma perspectiva completa. Na França, por 
exemplo, o primeiro autor moderno a ser estudado na Sorbonne foi Guillaume Apollinaire, em 1960, mais ou menos, depois de 42 anos de sua morte em 1918, por iniciativa de uma mulher, Marie Jeanne Durry. Objeto de tese podia ser, como Valéry foi ainda vivo. Mas dar curso para os alunos não podia. Isso é universal. O professor Fidelino de Figueiredo, que foi um guru dos cursos de Letras de nossa Faculdade naquele tempo, dizia: "Só se estuda autor morto, porque a obra já está fechada e você pode fazer uma avaliação". Eu partia de um ponto de vista diferente, inclusive devido ao que li no Anuário do Instituto de Inglês, da Universidade de Columbia, para o ano de 1940, livro que Mário de Andrade me deu. Lá havia um estudo de William York Tindall sobre a pesquisa erudita em literatura contemporânea, tão legítima quanto qualquer outra. Depois que me tornei professor de Teoria Literária em nossa Faculdade, em 1961, foi a primeira coisa que fiz. Em Literatura Brasileira os autores mais modernos que se davam eram Aluísio Azevedo e Raul Pompéia. Comecei a fazer o seguinte: no primeiro ano dava autores tradicionais, no quarto ano só dava os modernos, ajudado pelo aparecimento de edições acessíveis dos poetas, as da Editora do Autor, no Rio de Janeiro, dirigida por Rubem Braga, Fernando Sabino e Paulo Mendes Campos. Eles publicaram antologias de Cecília Meireles, Jorge de Lima, Carlos Drummond de Andrade, Manuel Bandeira, Murilo Mendes, Vinicius de Morais e outros. Com esses livros em mãos, pude dar cursos sobre os poetas modernos. Na Universidade de São Paulo, salvo erro, os primeiros cursos sobre os poetas a partir do Modernismo foram os meus. Em 1961.

E o Estudo analítico do poema, aquele que eu obriguei o senhor a preparar para edição recentemente, é de...

AC: De 64.

Já é todo baseado nesses textos do Modernismo.

AC: Já. Antes disso, dei um curso de análise do poema "Louvação da tarde" de Mário de Andrade, que acabou tendo muitas consequências. Desse seminário saiu a pesquisa em casa de Mário de Andrade, a cargo de Nites Teresinha Feres, Telê Ancona Lopez e Maria Helena Grembecki. Eu falei: "Vamos examinar a marginália do Mário de Andrade". Então arranjei uma verba com a Fapesp, que não dava verba para Literatura, só para Ciência; mas mostrei a eles que pode haver pesquisa em Literatura. A primeira foi para essas meninas e para Pérola de Carvalho analisar Machado de Assis. É preciso dizer que como minha disciplina era nova, sem tradição nem hábitos adquiridos, foi fácil introduzir cursos sobre autores recentes, contrariando a norma. Além disso, animei pesquisas sobre Mário e sobre Oswald. Encaminhei as três moças que mencionei para o estudo da obra de Mário, e Vera Chalmers para a de Oswald.

Fale um pouco sobre os acervos de Mário de Andrade e de Oswald de Andrade, esses tesouros dos dois principais modernistas... 
AC: Mário tinha manifestado informalmente à família dele o desejo de distribuir o seu acervo por várias instituições: Biblioteca Municipal, Biblioteca de Araraquara, Pinacoteca, Cúria - o que seria uma pena. A família não deu andamento e ficou tudo na casa da Rua Lopes Chaves, onde sua irmã foi morar. Um dia o irmão dele, Carlos de Morais Andrade, me chamou e disse: "Nós estamos numa situação um pouco complicada, porque precisamos dar um destino a isto. Além disso minha irmã está em situação difícil porque o marido morreu e ela precisa de dinheiro. Nós não queremos vender, porque o Mário não queria vender nada, mas queríamos ceder para alguma instituição que desse uma compensação pequena a ela. $O$ que você acha?" Estavam reunidos Carlos de Morais Andrade, o sobrinho Carlos Augusto de Andrade Camargo e Airton Canjani, casado com a irmã deste. Eu disse: "Há três possibilidades: transformar isto aqui numa Casa de Mário de Andrade; segunda, incorporar à Universidade de São Paulo; terceira..." Esqueci. Esqueci completamente a terceira hipótese. "Se vocês quiserem transformar isto numa Casa de Mário de Andrade a situação é boa porque, embora eu seja oposição, o atual governador do Estado, que é o Roberto de Abreu Sodré, foi meu companheiro de luta política contra o Estado Novo. O secretário do Governo é amigo meu, o Arrobas Martins, colega de turma na Faculdade de Direito. Eu sei que eles estão loucos para fazer uma Casa de Mário de Andrade." Aí eles conversaram, pensaram um pouco, e com grande bom senso disseram: "Queremos incorporar à Universidade".

JM: Realmente, foi o melhor.

AC: É o melhor, eu fiquei satisfeito. Eu não queria forçar essa hipótese porque...

Parecia que estava puxando a brasa para sua sardinha.

AC: Exatamente. Por isso eu dei as três alternativas. Eles toparam, fui falar com o Castello, que pegou fogo, encampou a ideia e promoveu tudo, depois de obter o consentimento da Reitoria. Morais Andrade me disse: "Não quero um tostão para mim, mas quero uma compensação para minha irmã" - fixando duzentos não sei o que, mil ou milhões, porque esqueci qual era a moeda. A reitoria achou tão pouco que deu quinhentos, quantia quase simbólica em face da qualidade e quantidade do acervo. Foi a partir daí que se formou no Instituto de Estudos Brasileiros (IEB-USP) o grande centro de estudos em torno de Mário de Andrade. Quanto ao Oswald foi o seguinte: a família dele não vendeu nem doou o acervo, mas depositou-o no mesmo Instituto de Estudos Brasileiros, com a condição de ficar sob minha responsabilidade pessoal.

O senhor era testamenteiro do Oswald de Andrade?

AC: Não. Eu era compadre dele, padrinho do Paulo Marcos. O acervo ficou muito tempo no IEB. Uma vez um americano queria pesquisar, me avisaram, fui 
lá, separei uma parte que podia ser consultada, uma parte que não podia, a não ser com autorização minha. Oswald não tinha papas na língua e nos seus papéis havia coisas cujo conhecimento me pareceu que devia ser adiado, inclusive para evitar problemas para a família. Daí a parte lacrada que nunca ninguém consultou; consultaram o resto. Um belo dia a Unicamp quis comprar e os herdeiros concordaram. O IEB estranhou, achando que o acervo lhe pertencia. Consultado pela diretora Myriam Ellis, esclareci tudo e o negócio foi feito com Campinas.

Porque havia uma doação em dinheiro, não é isso? A Unicamp estava disposta a comprar?

AC: E pagou muito bem. O acervo do Oswald era importante, mas não se compara com o de Mário. São algumas gavetas de papéis, enquanto o de Mário tinha uma coleção de quadros que era um museu, esculturas, quatrocentas gravuras, inclusive algumas de Albrecht Dürer, coleção de partituras, coleção de arte popular, coleção de imagens, quinze mil volumes na biblioteca: uma coisa monumental.

E os originais dos papéis dele, todos.

AC: Sim, a papelada com a correspondência também monumental.

Só queria fazer mais uma pergunta: o senhor mencionou de passagem sua atividade como crítico literário, que ficou na mira comentando tudo quanto saía do Modernismo. E isso por muitos anos?

AC: Eu fui crítico literário militante mesmo de 1941, em Clima, até 47 no Diário de S. Paulo, que acaba de ser ressuscitado. Nesse período, sobretudo de 43 a 47, porque Clima saía pouco, costumo dizer que tive uma sorte extraordinária, que os meus colegas de hoje não têm: volta e meia saíam livros de Mário de Andrade, Oswald de Andrade, Manuel Bandeira, Carlos Drummond, Murilo Mendes, Ciro dos Anjos, Graciliano Ramos, José Lins do Rego, etc. etc.

Não tinha mãos a medir: nem sabia o que comentar naquela semana...

AC: Não tinha mãos a medir: esses eram os livros da semana. Comparando com os de agora... Mas não vou dizer nomes, nem quero desmerecê-los... Quero lembrar uma coisa curiosa do meu tempo. Quando eu fazia crítica, havia uma espécie de silêncio em torno de Oswald de Andrade. O pessoal dizia: "Não escreva sobre ele, porque ele vem em cima".

Ele era briguento, não era?

AC: Eu senti isso na pele. 
E podia ser virulento.

AC: Eu pensava, não é possível, Oswald de Andrade é um escritor que está sendo menosprezado. Creio que fui a primeira pessoa da minha geração que escreveu algo longo sobre ele, três rodapés seguidos, fazendo uma série de restrições. Ele ficou louco da vida, desceu o pau em mim. O artigo dele está no Ponta de lança. De Mário de Andrade fiz uma interpretação, quando saíram pela primeira vez as Poesias completas: escrevi sobre a teoria estética dele dois longos rodapés; escrevi sobre Drummond, sobre Manuel Bandeira, sobre Murilo Mendes e os jovens que iam aparecendo. Sobre João Cabral de Melo Neto escrevi o primeiro artigo aqui no Sul, onde ninguém sabia quem era. A única informação sobre ele que eu tinha era de um amigo comum que dizia: "Tem um amigo meu no Recife que veio para o Rio agora, não sei se presta, disse a ele que você é crítico e sugeri que me passasse um exemplar do livro que publicou para te dar. Eu sei que ele tem uma dor de cabeça desgraçada." Eu só sabia isso do João Cabral. Pude escrever sobre Clarice Lispector, sobre João Cabral, sobre Guimarães Rosa, as grandes novidades do meu tempo. Tive uma sorte extraordinária. Como crítico valorizei demais o Modernismo e cheguei a adotar maneiras de escrever de Mário de Andrade, até que Lourival Gomes Machado me deu uma gozada, mostrando que eu continuava a escrever de maneira tradicional, apenas semeando de vez em quando uns "Me parece" ou "Lhe dizendo" iniciais.

JM: E fez escola também. Antonio Candido, se não existisse, precisaria ser inventado. Ele formou você, Walnice, formou o João Alexandre...

AC: Não, o João Alexandre não. O João Alexandre já veio formado.

JM: Eu levei o João Alexandre para você na rua Maria Antonia. Ele veio formado mas chegou a São Paulo e não conhecia ninguém.

AC: Eu conheci o João Alexandre no congresso de Assis, em 1961. Ele foi para Brasília, mas depois foi cassado lá e veio para São Paulo, onde acabou por trabalhar comigo.

JM: Aí o Gastão [de Holanda] me escreveu de Recife...

AC: O João já veio formado, não posso me gabar de tê-lo influenciado ou tido como aluno, como foi o caso de Walnice, Roberto Schwarz, Davi Arrigucci Jr., Teresa Vara, João Lafetá, Lígia Chiappini, para mencionar apenas os que foram também meus colaboradores no curso de Teoria Literária e Literatura Comparada. Eles e outros são críticos de primeira ordem e foi para mim uma sorte extraordinária tê-los como estudantes, orientandos e colegas. Cheguei a escrever que gostaria de ter escrito o ensaio de um deles (dá uma piscada para a entrevistadora). 
JM: Você se lembra de qual? Acho que pode falar sem ser em off, não? Não, deixa pra lá.

AC: Lembro: foi a análise de "Meu tio o Iauaretê", pela Walnice. Mas José, você precisa lembrar o seguinte: nossa posição é essa, mas no meio em que nós vivíamos havia uma atmosfera de gozação fantástica com o Futurismo.

JM: Mas olha, eu me lembro, o ambiente todo, em 50, 51, com o Nonê, o Mário da Silva Brito. O Ernani Campos Seabra e eu publicamos uma tradução da Dora Ferreira da Silva das Elegias de Duino.

\section{AC: Eu tenho.}

JM: Tiragem de cem, cento e poucos... Aquilo esgotou-se, nós não tínhamos dinheiro para fazer gravuras, então o Nonê fez duas ilustrações originais para cada exemplar. E nós fomos à casa do Segall para mostrar o livro e o Oswald de Andrade estava lá. Aí o Oswald disse assim: "Por que vocês não publicam O santeiro do mangue?" E o Segall disse: "Ah, e eu ilustro". Mas O santeiro do mangue, em 50, era impublicável. E no entanto é uma coisa que não tem nada de mais, hoje.

AC: Você lembra qual era o exemplo de poesia modernista que se dava de brincadeira, na Faculdade de Direito? "A lua lá vem surgindo/redonda como um tamanco/pedaço de telha é caco/urubu não tem pescoço".

Então, era gozação.

AC: Era gozação. Havia uma cantiguinha: "Maria, Maria/Maria Marinetti/teu pai é Graça Aranha,/tua mãe é Coelho Neto".

Essa conversa tem alguma coisa a ver com o fato do Lasar Segall ter feito uma série imensa chamada Mangue? E O santeiro do mangue, o trabalho com o poema do Oswald, acabou por não se fazer?

JM: Eu acho que não.

Mas não era mau...

JM: Não era mau, mas a gente não tinha coragem de publicar...

AC: Devo dizer a você o seguinte, José: a "Balada do mangue", do Vinicius, da qual te dei o autógrafo, saiu na Revista do Brasil e a revista foi apreendida.

Por causa da "Balada do mangue"? 
AC: Foi apreendida: por ser "poesia pornográfica".

JM: Isso foi no Estado Novo?

AC: No Estado Novo. Em 44.

No apagar das luzes.

JM: As coisas que a gente fazia... Primeiro era a ideia de fazer, depois muita gente procurava, de repente começaram a falar que eu tinha cultura, um blefe completo...

AC: Mas muita gente acreditou...

JM: Pois é. Eu me comparo muito ao Pacheco do Fradique Mendes. Outro dia soube de uma coisa engraçada, de que absolutamente não me lembrava. $\mathrm{O}$ Roberto Teixeira da Costa agora é presidente do Conselho do MAM. Então ele disse: "Eu estava mexendo na papelada do museu e encontrei a ata de fundação do Museu de Arte Moderna. E você foi o primeiro presidente." Eu não tinha a menor lembrança disso.

Esse daqui de São Paulo? Quando foi, 1949, 1950?

JM: Mais ou menos. Não tinha a menor lembrança. Se tivesse que ir a juízo eu ia errar, não? Eu fiz muita coisa por força de amigos, solicitações: o que eu tenho de dar em matéria de conselhos, se vivesse no século 19 seria conselheiro... Realmente, acabei fazendo coisas porque acho que o desenvolvimento cultural do país é uma coisa fundamental. Mas mais é por gosto, também. Então... E a gente procura ajudar... O IEB, procura apoiar... O IEB é uma das boas coisas... Esse projeto de doar nossa biblioteca à USP, o normal seria entregar ao IEB. Mas você não tem segurança, dadas as influências políticas, do que vai ser a Universidade daqui a vinte, trinta ou cinquenta anos. Aliás, o Jacques Marcovich, o reitor, concordou, disse isso mesmo. Então vai haver esse período de experiência, de 99 anos, se tudo correr bem aí passa definitivamente para a USP.

AC: Daqui a 99 anos você pára para pensar, se valer a pena redobra a dose.

O primeiro diretor do IEB foi Sérgio Buarque de Holanda?

AC: Sérgio inventou e deu configuração ao IEB, mas, vamos dizer, quem encorpou foi o Castello. O IEB é o Castello.

O senhor disse lá atrás que houve um momento em que achou o Modernismo o máximo. Ehoje, o que acha? 
AC: Continuo achando. Nesse ponto sou passadista, porque hoje ser modernista é ser passadista. Já veio a geração de 45 contra...

E depois o Pós-Modernismo...

AC: E o Pós-Modernismo. Mas eu continuo achando. O Modernismo é a grande revolução cultural do Brasil no século 20. Acho até que tudo mais decorre em grande parte das concepções dele. Não sei se exagero, mas acho uma coisa extraordinária o que ele fez. E no Modernismo a figura central foi Mário de Andrade. O Oswald, por exemplo, era uma pessoa muito interessante, muito divertida, mas não era homem de grande envergadura intelectual, nem de grande cultura. A pessoa que pensou o Brasil, que fez projetos culturais, foi Mário de Andrade. Influiu diretamente na cultura brasileira. Fez o plano do Serviço do Patrimônio Histórico. Fez o plano da Enciclopédia Brasileira. Transformou o Departamento de Cultura. E era um homem tímido, que não tinha sido nem funcionário público.

JM: Criou um departamento municipal, o de Cultura, que é modelo até agora.

AC: A primeira grande pesquisa musicológica foi ele quem fez. E também a Sociedade de Etnografia e Folclore, juntamente com a Dina Lévi-Strauss. Considero o Mário o grande intelectual brasileiro que mais serviços prestou à comunidade.

JM: Estou plenamente de acordo.

AC: Sem falar na obra que escreveu, inclusive essa coisa monumental que é a correspondência, de uma importância como não conheço outra. A do meu amado Proust, por exemplo, é lamentável. São 21 volumes de fofocas, queixas, banalidades, com pouca coisa relevante.

Como a fumigação...

AC: Ela vale como documento, para conhecer a vida de Proust, mas não tem substância. A correspondência de Mário de Andrade é do tipo e da importância da de Flaubert, por exemplo: debate intelectual, coisa séria. Eu acho que é um dos maiores monumentos da literatura do Ocidente.

JM: O que ele sacrificou, as obras que poderia ter escrito. Porque são milhares de cartas que ele escrevia a mão...

E isso, todas as noites. 
AC: Pensando que era obrigação moral dele, que não podia falhar. Sobretudo aos jovens que se dirigiam a ele. Oswald de Andrade, para caçoar de Mário, dizia: "Mário de Andrade quer é popularidade; qualquer analfabeto lá do Piauí escreve para ele, ele responde e faz cartaz no Piauí".

Será possível que o Modernismo tenha sido mais importante para o Brasil do que para $o$ resto do mundo?

AC: Bem mais importante, é outra coisa. Você vê, a partir daquele impulso inicial, saíram as revistas, a segunda fase da Revista do Brasil, essas revistas todas que o José reeditou, e mais isso e mais aquilo. Saiu a grande fermentação intelectual; e esses modernistas avançados, na maior parte, ou foram para o Partido Democrático ou para a esquerda. E aqueles modernistas mais tradicionais ficaram na direita e no PRP. Ora, do Partido Democrático e da redação de O Estado de S. Paulo, que acabou aceitando o Modernismo, saiu a Universidade de São Paulo. O piparote inicial foi a Semana de Arte Moderna que deu. A fundação da Universidade de São Paulo é uma coisa básica na cultura brasileira, porque transformou a cultura do Brasil em todos os setores. Sem querer forçar muito, ela foi devida ao grupo que completou o projeto da Semana de Arte Moderna: Júlio de Mesquita Filho, Fernando de Azevedo, Paulo Duarte, Antônio de Almeida Prado e outros. Eles não aceitavam a estética do Modernismo, mas desenvolveram muito da sua ideologia no campo da cultura. E há outro tipo de modernidade no Brasil, completamente diferente. A do Monteiro Lobato, por exemplo. Uma modernidade pragmática, voltada mais para a economia, o petróleo, a indústria editorial, o aço. É outra coisa. Muito bom, também, mas na parte cultural acho que a Semana de Arte Moderna foi fundamental. Continuo achando que é um fenômeno fundamental e nesse fenômeno a figura central é Mário de Andrade. Eu não sei como um homem que morreu com 51 anos de idade pôde deixar realizada aquela obra. Verifiquei isso em vários setores. No segundo ano da Faculdade tive um curso de Sociologia Estética com Roger Bastide. Como trabalho de aproveitamento fiz uma pesquisa sobre a mudança do gosto musical em São Paulo. O ano era 1940 e eu verifiquei que a partir da atuação de Mário no Departamento de Cultura, de 1935 a 1938, houve mudanças acentuadas, que registrei em gráficos. Por exemplo: a curva da ópera começou a descer e a da música de câmara começou a subir. Mário de Andrade tinha criado o Coral Paulistano, o Coral Lírico, o Quarteto Haydn, o Trio São Paulo e aberto o Municipal para o povo. Então senti como esse homem tinha mudado a sensibilidade de uma cidade.

JM: Para encerrar, então. Você fala do movimento modernista: vejam aqui a dedicatória autógrafa de Oswald de Andrade no primeiro exemplar de Memórias sentimentais, "À pintora da capa, o exemplar princeps". E de repente você vê na mesma página, no mesmo dia: "Para as mãos reais de dona Olívia Guedes Pentea- 
do, este volume pobre". Minha tese é que - esse era o único exemplar, o exemplar princeps - dona Olívia teria passado em casa dele e ele pegou o exemplar que tinha dado para a Tarsila e deu para dona Olívia. Isso define o Oswald de Andrade, completamente espeloteado. 